\title{
'Doing What is Right': Researching Intimacy, Work and Family Life in Glasgow, 1945-1960
}

\author{
by Sue Innes and Linda McKie \\ Glasgow Caledonian University
}

Sociological Research Online, Volume 11, Issue 2,

< http://umw. socresonline.org.uk/11/2/innes.html>

doi:10.5153/sro. 1256

Received: 6 Oct 2005 Accepted: 17 Mar 2006 Published: 30 Jun 2006

\begin{abstract}
Understanding discursive shifts over the twentieth century in relation to family roles, paid work and care is essential to any critical review of contemporary family theory and policies. This paper charts aspects of these shifts. An analysis of case records of the Royal Scottish Society for the Prevention of Cruelty to Children (RSSPCC), 1945 to 1960 is presented. Based upon these data we reflect upon the construction of the working-class family in the West of Scotland and draw upon one case study to illustrate issues further. This post-war period was one of rapid social and technological change. It is commonly perceived as a period of segregated gender roles, and in the UK a predominant male-breadwinner family model. The RSSPCC case records suggest that family lives and forms, particularly for those on low incomes, were diverse throughout this period. Although prosecutions for cruelty and neglect are dominant in perceptions of the society, most of its work was in material assistance, advice and surveillance. This latter aspect is considered in this paper.
\end{abstract}

\section{Keywords: Families, Child Protection, Gender, Paid Work, Care}

\begin{abstract}
A considerable number of mothers have, in their husbands' absence, drifted into habits and formed associations which have not been to the advantage of their homes and families. (RSSPCC Glasgow District Branch Annual Report, 1945: 10-11)
\end{abstract}

By advice, warning and, if necessary as a last resort, by prosecution, the Society causes lazy, drunken and neglectful parents to feed, clothe and treat their children in a proper manner... Many homes are reconstituted and brought to a happy, normal standard. (RSSPCC publicity leaflet, n.d. post-1945)

\section{Introduction}

1.1 This paper draws upon a qualitative analysis of 34 case records drawn from the archive of the Royal Scottish Society for the Prevention of Cruelty to Children (RSSPCC). The records for one family, constructed over a number of years, are considered as a case study. This illuminates key themes and issues in relationships between RSSPCC inspectors and families in the post war era of 1945 to 1960. In addition, a quantitative analysis of the 345 case records provides a context to qualitative data.

1.2 This archive is a rich data source on parenting and the inter-face between a charity, their inspectors and parents. Records exist for a century, from the late 1890s to early 1990s. The only extended study to emerge charts the changing thinking on, and practice in, child protection in Scotland from 1960-1989 (Robinson, 2001). It considers the poverty of families in the records, and the class and gendered assumptions that shaped interventions. The majority of interventions were initiated by parents, usually the mother, approaching the RSSPCC. Contrary to general assumptions, most cases did not lead to court cases or children being taken into care. Post-war and more recent RSSPCC practice has focused on keeping families together. In the history of child protection most attention has been paid to moral concerns for certain children, particularly children in poor families, or those in what were considered to be atypical family forms (Behlmer 1982 and 1998, Parton 1985, Land 1999). The RSSPCC archive records are an unusually rich social record of the domestic life of poor families and constructions of 'the family' that can be explored. Further, these records allow for the study of how inspectors worked with families to achieve what they considered to be adequate parenting through surveillance, support, and the resources and services offered to parents and children. 
1.3 Families are the subject of significant public and political concern, and of extensive current and recent social research. However, much less work has been undertaken on the social and cultural history of families in the $20^{\text {th }}$ century, or the ways in which inherited ideas inform current debate and policy. Historical sociology and the history of the family has focused primarily on two areas: family formation, kinship networks and obligations; and childhood and young adulthood. Most histories of the family, as Davidoff et al (1999) comment, have focused either on the marriage relationship or on constructions of childhood. As they also comment, an historical perspective based on functionalism continues to be influential. Other aspects, such as parental roles and responsibilities, and household management have been given less attention, although any focus on interventions in relation to children necessarily has implications for constructions of adequate parenting and 'functional' or 'problem' families. Again, although women's family roles in the period have been studied, family ideology of an earlier period have been viewed by some as reflecting women's domestic lives (Lewis 2000).

1.4 The history of family change post-1945, and up to 1960, is particularly under-researched (Kiernan et al. 1998), as is the history of the family since 1914 generally (Anderson 1995). This is exacerbated in Scotland where there is very little work on this topic. There is relatively little work on the history of poor and workingclass families, in part because sources (such as the RSSPCC archive) are relatively rare. Kiernan et al. (1998) study of single parent families over the $20^{\text {th }}$ century is particularly relevant, as the proportion of sole parents among families investigated was much higher than in the general population. Their focus on the discursive context of intervention offers a useful model.

\section{The Post-War Years}

2.1 The period 1945-1960 was chosen as it is a period in which family norms and policy appear to have been relatively coherent whereas from around 1965 rapid change in attitudes and behaviour had major implications for families (Silva and Smart 1999). While in the immediate post-war period there was social and family disruption (Murphy 1992, Turner and Russell 1995) this was swiftly followed by relative social stability and high employment.

2.2 Demographic changes included a marked increase in nuptuality and fertility; sustained growth in unmarried conception and rising divorce rates towards the end of the 1950s (Anderson 1995). This was also a period of shifting gender roles, albeit that post-war many women left the labour market. During the 1950s there was an increase in married women's employment coupled with changing ideas of marriage.

Nevertheless, in the UK, the presumption of the male breadwinner remained strong and was a premise to many social policies and social practices (Wilson 1980). Neighbourhood and housing redevelopment post war was followed by slum demolition and rehousing (Cree 1995). Improved health and material circumstances of working-class families resulted in a consequent increase in the health status of children. Changes in children's position in the family (Jamieson 1998) were evident and ideas of the modern, childcentred family became a cross-class norm, with more expected of mothers (Checkland 1982, Jamieson 1998, Lewis 2000). The raising of the school leaving age led to a longer period of child dependency and the notion of the teenage years was born. A growth in consumerism centred on family life and women's role in it, and the purchasing power of teenagers and young adults (Silva and Smart, 1999).

2.3 The policy context is one of post-war public concern about children's services and changes in how children were perceived as welfare recipients, foregrounding emotional and behavioural issues. At the same time there were anxieties about 'problem families' (WGPW 1948) and 'problem places' (Cree 1995). In Scotland there was a change towards recognising the strength of the bond between children and their natural parents, resulting in a greater emphasis on support for families and retaining families as 'intact' (Abrams 1998). Widespread hopes for a more just social world articulated by the Beveridge Report contributed to the culture in which agencies intervened in family life (Thane 1996, Finch and Summerfield 1991). As increased welfare provision and rising incomes affected the majority of families, policy focus turned to the social problems of families with ill health, large families, poor housing, where breadwinners were unemployed or unskilled workers in declining sectors of the economy (Thane 1996). Other problems, such as domestic violence and alcohol abuse, were less acknowledged (Wilson 1980, Robinson 2001). A high proportion of families in the RSSPCC records faced such problems.

2.4 Although at the time there were concerns about the 'functional decline' of the family and 'moral decay' (Lewis 2000), the post-war period is now seen as a 'golden age' of stability in the family (Jamieson 1998). In the same way that conceptions of the family that underpinned sociological writing in the post-war period contrast modern family forms with a supposed pre-industrial extended family (Hareven 1991), diversity in family form and intimate personal relationships is now commonly contrasted with a restrictive nuclear family form prevalent in the post-war period. ${ }^{[1]}$ In both cases change may be over-stated or rely on an overgeneralised view of the previous period. 
2.5 Many, but not all, twentieth century European welfare states incorporated into their development a 'male breadwinner' model of the family that assumed a married or cohabiting heterosexual couple, where the man undertook paid work and supported the woman's unpaid work of caring and the child dependants (Land 1999, Lewis 2000) ${ }^{[2]}$. In the post-war period models of the self-sufficient male breadwinner family were socially emphasised and reconstructed in the UK (Wilson 1980). Because that family model is predicated on a division between care and earning, prescriptive gender roles are played out in issues of providing that are distinguished from child care and household management and defined in terms of wage-earning. The assumption of the male-breadwinner family has, as has severally been argued, overlooks the circumstances of poor families lives and earning patterns. It also marginalises other family forms, particularly that of the mother-headed sole parent family, which is defined as a problem because women and children are without men to support them (Kiernan et al 1998). Fraser's (1989) view of the social as an arena of contestation and as a space where conflicts among rival interpretations of people's needs are played out is also highly relevant and can include a view of the need for a certain kind of family, and work and care pattern.

\section{Methodological Issues}

3.1 The use of terminology requires discussion. The concept of the 'problem family' is appropriate, since it was an emerging term and concern in the post-war period. But what is its converse? 'Functional' may be useful with its association with the family sociology of the period (Davidoff et al 1999). The phrase the RSSPCC inspectors use when a family is described as not needing surveillance is 'in good order'. This suggests a possible useful pairing of 'problem' versus 'orderly' families. Also noteworthy is that parents appear in the records as Father and Mother, not by their names. Children are also often not named. It is unclear whether this is a practice relating to confidentiality (names are on the top sheet of the case) but it has the effect of emphasising the role rather than the individual.

3.2 Because distinctions between families according to, for example, form and presence of breadwinner, are likely to play a defining role in what is seen as constituting a 'problem' or, 'orderly' family, such distinctions can be studied through the records. We would expect that agencies acting in a regulatory manner will make judgments and draw distinctions based on that model of the family and that they will be prescriptive in relation to family form and breadwinner/carer roles. However, Robinson (2001) suggests that such agencies, because of their day-to-day closeness to the difficult lives of poor families in the region, could also be pragmatic rather than prescriptive in views of families and in their interventions. The families in the records had an extremely limited material basis for acting out the gender roles and other practices developed initially in, and for, the bourgeois family (Davidoff et al, 1999).

3.3 In approaching the study of the records a number of research questions were considered. What families are seen and by whom? How are family concerns identified and interpreted? What is not included in case notes, and from a reading of these notes what was seemingly not discussed? Of particular interest was the possibility of differences in the RSSPCC inspectors' reports of, and interventions in, families where both parents are present or where there is only one parent. Further, does the presence of a male breadwinner cause inspectors to respond differently to families where neither parent is working or there is a single parent. And what of gender? Did inspectors presume, even prescribe, gender roles? And in the case of lone parent families how did inspectors grapple with gender, and roles and responsibilities?

3.4 The RSSPCC case records differ from the main kinds of documents discussed by May (2001) and Scott (1990) in that they are the official records of a private organisation, but a private organisation acting as an arm of the state. They are shaped, as official documents are, by professional practices and the intended audiences. The records could be used in court cases and are written with that in mind. Like many official documents they are part of recurrent administrative routines of the society. It will be important to analyse these formalities, which include a hierarchy of response/action from 'advice' and 'warning' to prosecution. There are variations within that, for example severely warned, and somewhat contradictory usages such as warned to continue the progress. As mentioned, the conclusion of a case will be that the family is 'in good order' but there are gradations: 'in reasonable good order', 'in fairly good order'.

3.5 The society saw its primary function as ensuring (by carrot or stick) that parents do 'what is right'. The available evidence is an interpretation for specific purposes, recording and justifying the RSSPCC's interventions. These are premised on the normative values of family life that inform their stated purpose. Thus, the conceptual frameworks and definitions of need in the records can be utilised to explore the ideas and interpretations that underpin those frameworks.

3.6 Historical sociology methodologies are very varied. ${ }^{[3]}$ In general, the approach to documentary evidence is influenced by the work of Foucault (1980), particularly the ideas of a 'history of the present' and his development of concepts of archaeology and subsequently genealogy. What is available to us to study is - 
and only is - discourse. That is to say that such documents cannot be usefully considered as representing a separate social reality that can be known through them, but are irreducible. A related point is that such documents also are, by their nature, a selection. Not all documentary evidence survives or is available to the researcher and there are usually reasons for what is recorded, retained or discarded (May 2001). This approach foregrounds the 'conditions of production' (Scott 1990) and focuses on what ideas are present in the narrative and how they are performed in terms of the actions taken (actions that include writing the report).

3.7 Examining the discursive construction and repositioning of ideas is particularly important in understanding social relations and practices that foreground 'knowing that' for their justification. The articulation in Foucault's later work, of power as constitutive of knowledge and knowledge as constitutive of power is useful in relation to concepts of gender, social structure and practices, including family practices. These are areas where power relations have depended on a view of some truths as outside human invention and as therefore legitimising power relations beyond question. We need to bear in mind that the classifications that shape the records are as important as statements of moral imperative are, and need to pay attention not only to versions of events and prescriptive statements but to how the records present some behaviours and relationships as natural and self-evident (Foucault 1980, Scott 1990) and how interpretations of need can be presented as indisputably factual (Fraser 1989).

3.8 The quantitative analysis of the 345 records for the period 1945 to 1960 shows:

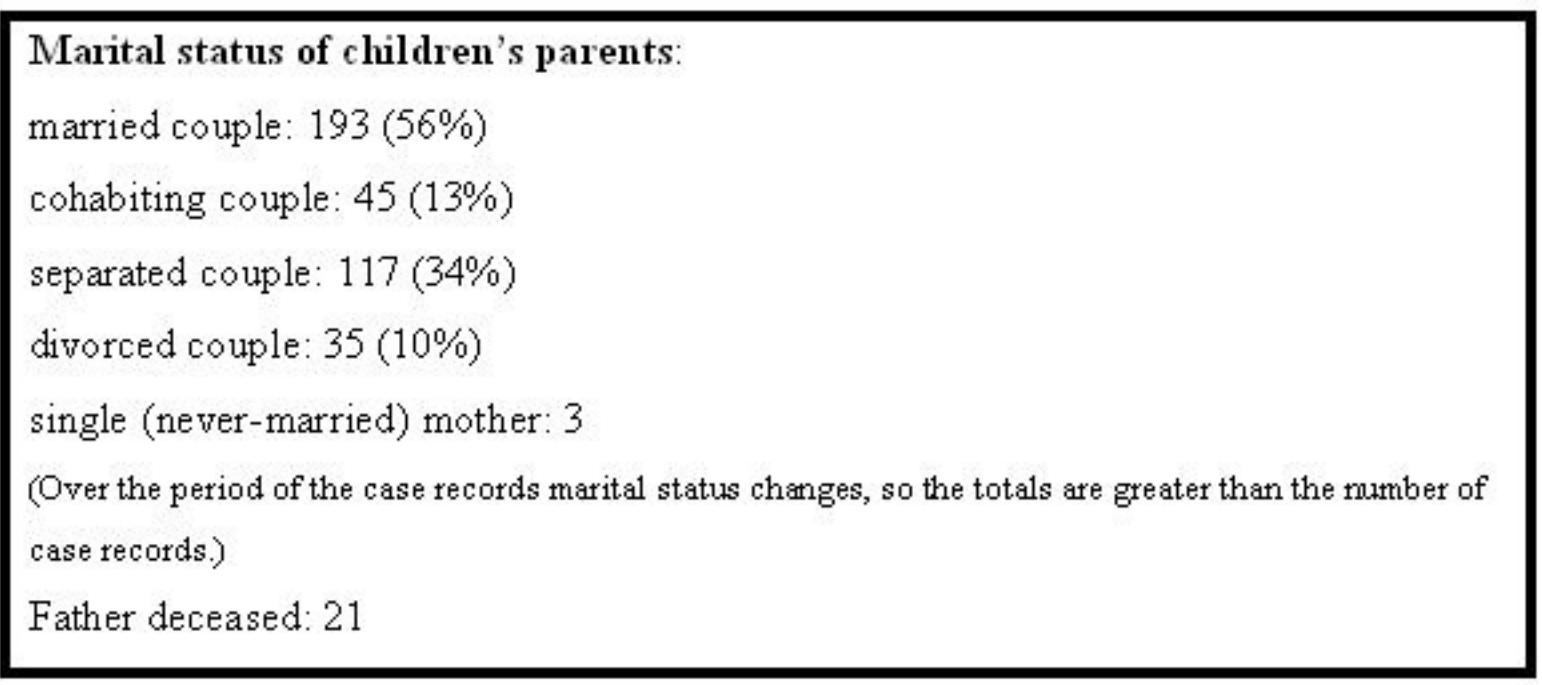

The most common employment situation is that of a two-parent family where the father is unemployed and the mother a housewife. The second most common situation is the father employed and the mother a housewife. In nine cases the mother is employed and the father unemployed. (Again employment status of parents changes over duration of case.)

Employment status of children's parents:

unemployed father: $139(40 \%)$

unemployed mother: 5

employed father: $90(27 \%)$

employed mother: $44(13 \%)$

father in casual employment: $37(11 \%)$

mother in casual employment: $35(10 \%)$

father's employment status not known: $63^{*}$

mother's employment status not known: 3

(*This may mean father is not present, or no longer alive, or in prison.)

In eight cases the father is imprisoned and in one case the mother is (for all or part of the duration). 
In terms of housing the majority of families lived in accommodation rented from the council $(n=202 ; 58 \%)$, followed by privately rented $(n=115 ; 33 \%)$, and 12 families were in owner-occupied housing. Five families were noted as living in 'condemned housing'.

\section{The Case Study}

4.1 An in-depth exploration of roles in families, and the relationships between RSSPCC inspectors and parents, is offered in a case study of one family. This approach to reporting data also allows for attention to genealogy (Foucault 1980) and the 'conditions of production' (Scott 1990). This case was chosen as it spans 12 years, almost the whole of the study years, that is from 1945 to 1960 . Further, the records were copious and legible.

4.2 The RSSPCC classification of the 'nature of wrong' is 'father not providing'. Reviewing material over the years it is hard not to agree with this initial assessment by the then inspector. The father, over the duration of the record, is often unemployed, although sometimes in work for different lengths of time. The first time the mother contacts the society she has a baby (approx two weeks old), has had no money from the father for two weeks, and he has been drunk and aggressive. Her own mother had helped but an aggressive intervention by the father had ended that source of support. They are squatting in one room in a condemned house. There is no gas or electricity but the room is 'clean and well enough furnished'. (They later move to a council house.) The RSSPCC intervenes with the National Assistance Board (NAB), which makes an emergency payment. Two weeks later a similar complaint is made by the mother and included in the record is a report of police intervention because he had attacked her. Again the RSSPCC intervene with the NAB, which had initially been reluctant to help. The RSSPCC also initiates a prosecution of the father for 'child neglect ${ }^{[4]}$ and he is sentenced to 30 days imprisonment.

4.3 The story is, from the outset, told in terms of a victimised woman and a man who is not shouldering his responsibilities. 'The mother said the father is prone to drinking and will not go to his work ...' 'The mother said she had not had anything to eat since Saturday last and a neighbour had given her a cup of tea. She borrowed dried milk for the baby but there was not enough left to make another feed. The mother was completely destitute...' 'Mother complained of father lying in bed - refuses to work ...' The case mainly consists of a repeated pattern that, from time to time, when he gets his benefit or wages, he does not come home with it but drinks and gambles it, eventually arriving home between one and three days later. The interventions are occasioned either by the mother contacting the society or are follow-up visits. The mother and the RSSPCC persistently try to get the man to function as an effective breadwinner. The inspector's role is paternalist, a good father, as opposed to the bad father or poor parent. The mother is presented as fulfilling her domestic role well in poor circumstances. There are fairly long periods when the father 'does not give any trouble as far as money is concerned ' and the case is dormant, reactivated when the pattern recurs. Variations in the story are her seeking help for rent arrears and threatened eviction or for electricity cut off for non-payment.

4.4 The inspectors are not reticent in their views: 'He is a poor worker, but the mother appears quite a welldoing person'... 'The father appears to be a pretty useless type as far as work is concerned. He was in bed at time of visit!'... 'The Mother is quite a clean type of woman and always looks after her children in a satisfactory manner'. On occasion we are informed that the father is caring for, or cooking meals for the children and, when the mother is, later, in hospital he is 'coping well so far' and 'is still coping well' . The RSSPCC initiates a second prosecution for 'child neglect' and he is sentenced to two months. Two more instances of domestic abuse, described as 'quarrelling', are recorded. There are ten further instances of the father not returning with wages or benefit.

4.5 Then, it seems after 32 pages of case records there is progress! He has been in work for over a year: 'father is still working, rent is clear, mother stated father is doing well and handing in his wages'. CASE CLOSED. But two years later the case resumes, with the familiar words. They now have eight children (all boys), he loses his job soon after the case re-opens and they are threatened with eviction and the electricity has been cut off. There are five more repetitions. The case enters a new phase with the involvement of a woman visitor (requested by the health visitor), who effectively takes over money management for the household, negotiating to get the electricity back on and collecting from them and paying the money for the rent, rent arrears and electricity arrears. Indeed she takes over many aspects of their lives, visiting irregularly but often at a frequency of every 2-3 days. She organises clothes and shoes from various welfare sources and a new bed from the society. This is the first time any record of resistance enters the case record: 'Christopher is a very strange wee boy and wouldn't allow W/V [woman visitor] to dress him.' The W/V becomes more ambitious and organises the father to buy paint and paper and redecorate the living room. 'I instructed Mother to get Father to get on with it over the weekend '. 
contraception. At least six times the mother fails to keep her appointment at the Family Planning clinic until the woman visitor gets her a second-hand coat to wear and accompanies her there personally. The father is violent again and the W/V contacts his probation officer. The mother then charged him with serious assault. 'He got 6 months deferred sentence. The home was clean and the older boys were at school.... Paul's bottom is fine now'.

4.7 Following two subsequent incidents recorded of domestic violence the case is transferred back to an inspector 'due to father's conduct'. But there is no record of any other visit until almost a year later in which the father is reported as employed, the children and home clean and orderly and 'all appears to be satisfactory'. CASE CLOSED.

4.8 There the RSSPCC record ends. There is one further document in the file, dated six years later. Its nature in unclear but it appears to be a note of a communication from the police. Christopher, now 9, has been taken home by the police after they found him attempting to housebreak. 'Christopher was poorly clad and claimed not to have eaten since yesterday morning'. The police found the house empty, although the father was expected back after 10.00. Five other children were on the streets and three other children in detention centres; 'mother deceased' .

\section{Discussion}

5.1 As a case study of a 'problem family' it could hardly be more exact in fitting the received view. If it were fiction - and there are fictional constructions of the Glasgow family that have many of the same characterisations - it might well be dismissed as clichéd. Regardless of concerns about what is recorded and why (May 2001), there are a number of themes that might be drawn out.

5.2 Gender roles are clearly delineated. The father's role is to 'provide' and to give no trouble. The mother's is expected to keep the children clean, clothed and fed and the house clean. She is also expected to manage the money that the father brings home, avoiding debt. (The extent to which that is close to impossible in the circumstances is not evident in the records.) The father's domestic contributions are recognised, but are not considered to be that relevant. Roles in relation to the societal change in the post war period might be summarised as to learn to manage; to be obedient and grateful; to not cause trouble. The key values evident were those of fathers working and earning while mothers were central to household cleanliness. Sobriety for parents, especially mothers, was considered to be of prime relevance.

5.3 The parents are presented as subjects for interventions and these are required because of their unfortunate or self-created circumstances, in this case the father's behaviour. The inspectors do not consider the consequent loss of rights to privacy, or having a 'say'. The children were silent although they are the stated reason for the society's role. The inspector and the woman visitor in every report list whether or not children were seen. Children remain the objects rather than subjects of the record. They are not presented as individuals with rights; rather, children are to be seen and not heard.

5.4 But the interventions and values are not always as straightforward as may at first, and from that case, seem. From other cases it is interesting to note that available parents to provide and care for children appears to have been considered more important than retaining intact original families. In one case where the mother moves on to another man, since he's willing to provide for the children and the new one on the way (which is his) that's clearly fine by the society. The warnings now include him: 'Both mother and paramour severely warned of their responsibilities'. A two-parent family is not always seen as desirable: In another case: 'Advised the mother not to marry as is not dependable and there is a strong possibility that he will continue to be unfaithful when he tires of family life'. In the (long and complicated) case of a 'dishonest' woman - 'Relations between Mother \& Father are not good \& mother is threatening to leave the home, this may be best for children'.

5.5 The disciplinary function of the records, or, to put it another way, poor families' behaviour being constrained and shaped to fit a certain view of how things should be, are a close to perfect Foucauldian model (1970), in that the role of the inspectors and women visitors is to cause the families to discipline themselves. Again it's worth noting the phrase used when a case is closed: 'in good order' - this is an ordering of the social. In a telling twist of language: 'Mother spoken to by District Inspector and advised to be truthful and so be able to accept help offered'. An interpretation of this note is that the problems are all to do with the mother's behaviour. The inspector is clearly seeking the compliance of the mother and here again Foucault (1970) might have proposed that surveillance is followed by calls to self discipline and ultimately compliance with the model of the family relevant to the RSSPCC inspectors.

\section{Concluding Comments}

6.1 The RSSPCC exercised a great deal of power over the families that came within its purview. This evolved 
against a backdrop of changing structures of welfare. The growth in public provision of health, social care, housing and education changed the material expectations of families and the RSSPCC. Yet these changes in material expectations must be considered alongside models of family life and notions of the good as opposed to the problem family. People sought assistance from the RSSPCC for financial and housing problems, and domestic violence, only to find themselves the subjects of intense surveillance, of child health and school attendance and of sources of income, domestic work and cleanliness and gender roles. Yet questions of 'discipline' need careful consideration. These records can be read as an over-arching case study of a derogation of individual liberties and family privacy among the poor. They might also be read as supporting the argument of the intensification of social discipline of private life in the 19th and 20th centuries with the social conservatism in the emphasis on the privacy of the (patriarchal) family. As Gordon (1990: 4) comments 'in policing private behaviour, one person's rights may be established only by invading another person's privacy.'

6.2 Another striking aspect is the degree to which cleanliness seems to be a value that over-rides others, or perhaps has a key symbolic role. Cleanliness is the first and main consideration of inspectors: it functions to stand for adequate care - the notion that a household could be dirty but loving (or clean but abusive) is not even countenanced. Women (and families) demonstrated their co-operation with the society by their efforts to clean. In instructions to clean and wash, and sometimes the close supervision of it being done, there is no reflection of what very hard physical labour, against considerable odds, cleaning was. When families lived in one room it is almost an aside in the record rather than given prominence in the family's social circumstances (taken for granted - no need to be noted). ${ }^{[5]}$ The inspectors and women visitors functioned much like the contemporary TV programme 'How clean is your house'. In one report there's a succinct 'Heads \& Beds clean'. Inspections by women visitors were not superficial: 'frock clean, but underclothing in need of washing'. It contrasts to, and reinforces, the values of the 'respectable' workingclass that bought strongly into the importance of cleanliness and putting a good front on things. Women scrubbing their doorsteps and hiding their lives behind net curtains were also creating, or observing, a distinction that mattered - a scrubbed and bleached threshold was a declaration, the net curtains a barrier, these were households that 'the cruelty man' could have no excuse to enter.

6.3 Scott (1990) suggests that the first questions that should be posed in relation to the meaning of any document is 'what is it and what does it tell us?' We need to add: what does the document tell us about social practices and policies? And who is this record written for, with what aims? Further, the researcher might want to ask, what outcome is achieved by telling the story in this way and for whom? It is easy to judge the outcomes with the benefit of hindsight - but is that ever useful? A key issue in any analysis of archive data is how to bridge theory and archival material; in short, how to approach the detail of the deconstruction of the case records. It is not possible to read off from Foucault's work an associated methodology but the records examined are examples of what Foucault described as an interplay between a 'code' which rules ways of doing things (how people are to be graded and examined, things and signs classified, individuals trained, etc.), and the production of discourses which serve to found, justify and provide reasons and principles for those ways of doing things.

\section{Notes}

${ }^{1}$ There are recurrent periods of moral panic with regards to 'the family' and anxieties particularly projected on to lower-class families (see Bernardes 1997).

${ }^{2}$ In a number of Nordic countries, most notably Finland, welfare states adopted a model in which women were incorporated into labour markets. However, the UK, France and a number of other European governments based welfare state policies, practices and benefits on the male breadwinner model.

${ }^{3}$ The boundaries between sociology, economic and social history and political sociology cannot be clearly drawn and historical sociology draws upon a range of methodologies.

${ }^{4}$ Section 12, Children and Young Persons (Scotland) Act 1937

${ }^{5}$ Some re-housing had begun in the inter-war period and the massive relocation of working-class families to the peripheral estates and new towns was at the planning stage - yet what appears from more recent accounts as its primary purpose, the improvement of density and availability of indoor plumbing, are not reflected in these accounts. Nor is any recognition of the practical difficulties of managing a wash in one room plus the Scottish climate, or of the discouraging impossibility of getting a room heated by an open fire and grimed by decaded/centuries of poverty to show any kind of difference. It is not easy to tease out, either, the standards of cleanliness that would count as adequate. We suspect it was a standard that would not be recognised as particularly clean now. The majority of parents lived in rented accommodation in 


\section{References}

ABRAMS, L. (1998) The Orphan Country. Edinburgh: John Donald.

ANDERSON, M. (1995) Approaches to the History of the Western Family 1500-1914 . Cambridge: Cambridge University Press.

BEHLMER, G. (1982) Child Abuse and Moral Reform in England, 1870-1908. Stanford: Stanford University Press.

BEHLMER, G. (1998) Friends of the Family: The English Home and its Guardians, 1850-1940. Stanford: Stanford University Press.

Bernardes, J. (1997) Family Studies. An Introduction. London: Routledge.

CHECKLAND, O. (1982) 'Maternal and Child Welfare' in O. Checkland and A. Lamb (eds.) Health Care as Social History: The Glasgow Case. Aberdeen: Aberdeen University Press.

CREE, V. (1995) From Public Streets to Private Lives: The Changing Task of Social Work . Aldershot: Avebury.

DAVIDOFF, L., Doolitte, M., Fink, J. and Holden, K. (1999) The Family Story: Blood, Contract and Intimacy, 1830-1960. London and New York: Longman.

FINCH, J. and Summerfield, P. (1991) Social Reconstruction and the Emergence of the Companionate Marriage, 1945-59, in D. Clark (ed) Marriage, Domestic Life and Social Change. Writings for Jacqueline Burgoyne, 1944-88. London: Routledge.

FOUCAULT, M. (1970) The Order of Things: An Archaeology of the Human Sciences . London: Tavistock.

FOUCAULT, M (1980) Power/Knowedge: Selected Interviews and Other Writings 1971-1977 . Brighton: Harvester.

FRASER, N. (1989) Unruly Practices: Power, Discourse and Gender in Contemporary Social Theory . Minneapolis: University of Minnesota Press.

GORDON, T (1990) Feminist Mothers. Basingstoke: Macmillan.

HAREVEN, T (1991) Synchronising Individual Time, Family Time and Historical Time in J. Bender and D. Wellbery (eds) Chronotypes. Stanford, California: Stanford University Press.

JAMIESON, L. (1998) Intimacy: Personal Relationships in Modern Societies. Cambridge, Polity.

KIERNAN, K., Land, H. and Lewis, J. (1998) Lone Motherhood in Twentieth-Century Britain . Oxford: Clarendon Press.

LAND, H. (1999) The Changing Worlds of Work and Families in S. Watson and L. Doyal (Eds.) Engendering Social Policy. Buckingham: Open University Press.

LEWIS, J. (2000) Family Policy in the Post-War Period in S.N. Katz, J. Eekelaar and M. Maclean (eds.) Cross Currents. Family Law and Policy in the US and England . Oxford: Oxford University Press.

MAY, T. (2001) Social Research: Issues, Methods and Process. Buckingham: Open University Press.

MURPHY, J. (1992) British Social Services: The Scottish Dimension. Edinburgh: Scottish Academic Press.

PARTON, N. (1985) Governing the Family: Childcare, Child protection and the State . London: Macmillan,

ROBINSON, C. (2001) Children in Good Order: A study of constructions of child protection in the work of the RSSPCC in the West of Scotland, 1960-1989. Unpublished PhD thesis. Stirling: University of Stirling. 
ROYAL SCOTTISH SOCIETY FOR THE PREVENTION OF CRUELTY TO CHILDREN (1945) Glasgow District Branch Annual Report. Glasgow: RSSPCC

SCOTT, J. (1990) A Matter of Record: Documentary Sources in Social Research . Cambridge: Polity.

SILVA, E. and Smart, C. (eds.) (1999) The New Family? London, Sage.

THANE, P. (1996) Foundations of the Welfare State. Harlow: Longman.

TURNER, B. and Russell, T. (1995) When Daddy Came Home: How Family Life Changed Forever in 1945 . London: Hutchinson.

WILSON, E. (1980) Only Halfway to Paradise: Women in Post-War Britain 1945-1968 . London and New York: Tavistock.

WOMEN'S GROUP ON PUBLIC WELFARE (WGPW) (1948) The Neglected Child and his Family . Oxford: Oxford University Press. 